\title{
Effect of Cinnamon (Cinnamomum cassia) as a Lipid Lowering Agent on Hypercholesterolemic Rats
}

\author{
Sonia Rahman ${ }^{1}$, Halima Begum ${ }^{2}$, Zaida Rahman ${ }^{3}$, Ferdous Ara ${ }^{4}$, \\ Md. Jalaluddin Iqbal ${ }^{5}$, Abul Kalam Mohammad Yousuf ${ }^{6}$
}

\begin{abstract}
Background: Dyslipidemia is one of the important causes of cardiovascular disease related mortality and morbidity. Recently it has become a significant issue in public health problem of developing countries. The purpose of the study was to find a suitable solution for reducing blood lipid in dyslipidemic patients by conducting a research on the effect of cinnamon in hypercholesterolemic rats. Objective: To study the lipid lowering effect of Cinnamomum cassia on experimentally induced hypercholesterolemic rats. Materials and Methods: This study was done on 30 male Long Evans rats weighing about 200-210 gram. For convenience, the study was divided into two experiments - Experiment I and Experiment II. In experiment I, 12 animals were divided into two groups. One was Group $A(n=6$, control group) fed on laboratory diet and the other was Group B $(n=6)$ fed on laboratory diet and cinnamon for 35 days. In experiment II, the remaining 18 rats were fed fatty mixture diet containing $1 \%$ cholesterol and $0.25 \%$ cholic acid. The hypercholesterolemic rats were then divided into 3 groups, Group $C, D$, and $E$ ( $n=6$ in each group). Group $D$ and Group $E$ were additionally fed on cinnamon powder and tablet atorvastatin for 35 days respectively. Serum TC, TG, LDL-C and HDL-C were measured after 35 days. Results: Fatty mixture diet increased TG, TC and LDL-C significantly. Cinnamon treated fatty mixture diet group showed that Cinnamomum cassia decreased plasma TC, TG and LDL-C. Atorvastatin therapy decreased TC, TG and LDL-C levels significantly compared with the lowering effect of cinnamon. Conclusion: The results of this experimental study indicate that Cinnamomum cassia can act as a hypocholesterolemic agent and thereby can improve cardiovascular functions.
\end{abstract}

Key words: Cinnamomum cassia, Dyslipidemia, Hypercholesterolemic rats

J Enam Med Col 2013; 3(2): 94-98

\section{Introduction}

Hypercholesterolemia is a condition characterized by very high levels of cholesterol in the blood. Cholesterol is a waxy, fat-like substance that is produced in the body and obtained from foods that come from animals (particularly egg yolks, meat, poultry, fish, and dairy products). The body needs this substance to build cell membranes, make certain hormones, and produce compounds that aid in fat digestion.

1. Former M Phil student, Department of Pharmacology and Therapeutics, Sir Salimullah Medical College, Dhaka

2. Assistant Professor, Department of Pharmacology and Therapeutics, Enam Medical College, Savar, Dhaka

3. Associate Professor, Department of Pharmacology and Therapeutics, Enam Medical College, Savar, Dhaka

4. Professor, Department of Pharmacology and Therapeutics, Sir Salimullah Medical College, Dhaka

5. Assistant Professor, Department of Pharmacology and Therapeutics, Sir Salimullah Medical College, Dhaka

6. Assistant Professor, Department of Pharmacology and Therapeutics, Northern International Medical College, Dhanmondi, Dhaka

Correspondence Sonia Rahman, Email: mrtsr2003@yahoo.com 
Recently, hypercholesterolemia has been associated with enhanced oxidative stress related to increased lipid peroxidation. Increased generation of oxidized LDL is a major factor in the vascular damage associated with high cholesterol levels. Hence, the inhibition of oxidative stress under hypercholesterolemic conditions is considered to be an important therapeutic approach and efforts have been made to identify the antioxidative functions of various medicinal plants. ${ }^{1}$

The use of plant extracts in managing various disorders is currently a common practice. Many plant materials are also in current use as supplements. Sometimes the aim is to lower the levels of some markers of disease states in order to improve health conditions. An example may be found in the use of substances that lower the cholesterol level in the system. Many studies indicate that lowering the serum cholesterol may prevent, control and even reverse artherosclerosis and coronary heart disease. Low triacylglycerol and low-density lipoprotein cholesterol (LDL-C) levels or high density lipoprotein cholesterol (HDL-C) levels are desirable health outcomes known to have resulted from the use of some plant materials. ${ }^{2}$

Cinnamon is a plant that has a variety of uses among many different cultures, from spicing up foods to deterring germs from growing. There are actually two main forms of cinnamon that are commonly found in foods. The first, Cinnamomum verum, also known as "true" cinnamon or ceylon cinnamon, is commonly used in sweet pastries. On the other hand, Cinnamomum cassia, also known as cassia, Chinese cinnamon or "bastard" cinnamon, is used as a stronger spice in a variety of foods. In fact, it is cassia-based cinnamon that is often seen on the grocery shelves and is most often cheaper than true cinnamon. ${ }^{3}$

Cinnamate, a phenolic compound found in the inner bark of cinnamon lowers cholesterol level in high fat fed rats by inhibiting hepatic HMG Co-A reductase activity. ${ }^{4}$ Polyphenolic polymers found in cinnamon have antioxidant activity and have been shown to reduce oxidative stress in dose dependent manner through inhibition of 5-lipoxygenase enzyme. ${ }^{5}$ Cinnamon has a long history of use as spice and flavoring agent. Indeed, there are reports of cinnamon being imported to Egypt from China as early as 2000 BC. Cinnamon is mentioned in Chinese text written 400 years ago as well as in the Bible. ${ }^{6}$ The aim of this study was to find a suitable solution for the hypercholesterolemic patients by conducting a research of cinnamon's effect on rats.

\section{Materials and Methods}

This experimental study was carried out in the department of Pharmacology and Therapeutics in Sir Salimullah Medical College and Bangladesh Centre for Scientific and Industrial Research (BCSIR) from July 2011 to June 2012.

\section{Preparation of the cinnamon powder}

Cinnamon powder was obtained from cinnamon bark which contained cinnamonaldehyde. The cinnamon powder was produced by crushing sun-dried cinnamon bark in a grinder machine.

\section{Chemicals}

Cholesterol and cholic acid (manufactured by Loba Chemic) and atorvastatin (manufactured by Beximco Pharmaceuticals) were purchased from the local market in Dhaka. A mixture of cholesterol, cholic acid and standard laboratory diet for rats had been administered to each rat per day for 35 days. $^{4}$

\section{Animals}

The study was performed on total number of 30 healthy adult Long Evans (Rattus Rattus) rats weighing between 200 to $210 \mathrm{gm}$ collected from the BCSIR laboratory. The chosen animals were housed in cages separately at normal atmospheric temperature between 26 to $29^{\circ} \mathrm{C}$ under good ventilation and were given water and standard balanced diet. Animals were randomly distributed into five groups of six animals in each. Each cage was labeled for identification of different groups.

\section{Experiment I}

Experiment I was conducted to demonstrate the effect of Cinnamomum cassia on normal adult male rats. For this purpose a total number of 12 rats were taken and was divided into two groups containing six animals in each group.

Group A: Each animal received laboratory diet 20 gm/day and distilled water for 35 days. 
Group B: Each animal received 15\% powder of Cinnamomum cassia mixed with laboratory diet $20 \mathrm{gm} /$ day for 35 days.

\section{Experiment II}

Experiment II was conducted to demonstrate the effect of Cinnamomum cassia on hypercholesterolemic rats. For this purpose a total number of 18 rats were taken and divided into three groups containing six animals in each group.

Group C: Hypercholesterolemic group that received fatty mixture diet (normal laboratory diet plus $1 \%$ cholesterol with $0.25 \%$ cholic acid) for 35 days.

Group D: This group received fatty mixture diet with $15 \%$ powder of Cinnamomum cassia for 35 days.

Group E: This group received fatty mixture diet and tablet atorvastatin at the dosage of 0.2 $\mathrm{mg} / \mathrm{kg}$ body weight administered orally by gastric intubation daily for 35 days.

\section{Collection of blood specimens}

The rats were kept fasted overnight before taking the blood samples. All the animals were anesthetized with diethyl ether and sacrificed. Blood samples were collected in test tubes and allowed to coagulate at room temperature. It was then centrifuged at $3000 \mathrm{rpm}$ for 30 minutes in a centrifuge machine. The clear nonhemolysed supernatant sera was quickly removed and stored at $-20^{\circ} \mathrm{C}$ for biochemical analysis of serum lipid profile at the Biochemistry department of Sir Salimullah Medical College.

\section{Biochemical Analysis}

After collection of all blood specimens, serum total cholesterol (TC), serum high density lipoprotein cholesterol (HDL-C) and serum triglycerides (TG) were measured by enzymatic colorimetric (CHOD-PAP) method. Low density lipoprotein cholesterol (LDL-C) was calculated by Friedewald's formula.

\section{Statistical analysis}

The data were analyzed using unpaired $t$ test. Results were expressed as mean $\pm \mathrm{SE}$ and $\mathrm{P}$ values $<0.05$ and $<0.01$ were considered statistically significant and highly significant respectively.

\section{Results}

Experiment I: Table I shows the effect of cinnamon on serum lipid profile of adult male rats. Serum total cholesterol, serum LDL cholesterol, HDL cholesterol and serum triglyceride levels did not show any significant difference between the Cinnamomum cassia treated group (Group B) and the control group (Group A).

Table I: Effect of cinnamon on serum lipid profile of adult male rats (A vs B)

\begin{tabular}{|l|c|c|c|}
\hline Parameters & $\begin{array}{c}\text { Group A (n=6) } \\
\text { Mean } \pm \text { SE }\end{array}$ & $\begin{array}{c}\text { Group B (n=6) } \\
\text { Mean } \pm \text { SE }\end{array}$ & P values \\
\hline $\begin{array}{l}\text { Serum total } \\
\text { cholesterol }(\mathrm{mg} / \mathrm{dL})\end{array}$ & $71.17 \pm 1.59$ & $69.83 \pm 3.04$ & $>0.05$ \\
\hline $\begin{array}{l}\text { Serum TG }(\mathrm{mg} / \mathrm{dL}) \\
\text { Serum HDL } \\
\text { cholesterol }(\mathrm{mg} / \mathrm{dL})\end{array}$ & $78.10 \pm 2.45$ & $76.33 \pm 1.93$ & $>0.05$ \\
\hline $\begin{array}{l}\text { Serum LDL } \\
\text { cholesterol }(\mathrm{mg} / \mathrm{dL})\end{array}$ & $26.61 \pm 2.23$ & $23.90 \pm 6.00$ & $>0.05 \pm 4.87$ \\
\hline
\end{tabular}

Experiment II: Table II shows the effect of fatty mixture feeding on serum lipid profile of adult male rats. Serum total cholesterol, serum LDL cholesterol, and serum triglyceride levels showed significant difference between the fatty mixture diet group (Group $\mathrm{C}$ ) and the control group (Group A). But there was no change in serum HDL-C level. Table III shows the effect of cinnamon on serum lipid profile of adult male rats fed with fatty mixture diet. Serum total cholesterol, serum LDL cholesterol, and serum triglyceride levels decreased significantly in Group D compared to Group C. But there was no change in serum HDL level. Table IV shows the comparison of serum lipid profile parameters between 'fatty mixture diet + cinnamon fed' and 'fatty mixture diet + atorvastatin fed' adult male rats. It was found that atorvastatin significantly lowered serum total cholesterol, serum triglyceride and serum LDL cholesterol levels compared with the lowering effect of cinnamon. But there was no change of HDL level. 
Table II: Effect of fatty mixture feeding on serum lipid profile of adult male rats (A vs C)

\begin{tabular}{|l|c|c|c|}
\hline Parameters & $\begin{array}{c}\text { Group A }(\mathrm{n}=6) \\
\text { Mean } \pm \mathrm{SE}\end{array}$ & $\begin{array}{c}\text { Group C }(\mathrm{n}=6) \\
\text { Mean } \pm \mathrm{SE}\end{array}$ & P values \\
\hline $\begin{array}{l}\text { Serum total } \\
\text { cholesterol }(\mathrm{mg} / \mathrm{dL})\end{array}$ & $71.17 \pm 1.59$ & $136 \pm 3.74$ & $<0.01$ \\
$\begin{array}{l}\text { Serum TG }(\mathrm{mg} / \mathrm{dL}) \\
\begin{array}{l}\text { Serum HDL } \\
\text { cholesterol }(\mathrm{mg} / \mathrm{dL})\end{array}\end{array}$ & $31.50 \pm 0.10 \pm 2.45$ & $106.5 \pm 2.85$ & $<0.01$ \\
\hline $\begin{array}{l}\text { Serum LDL } \\
\text { cholesterol }(\mathrm{mg} / \mathrm{dL})\end{array}$ & $26.61 \pm 2.23$ & $83.81 \pm 5.6$ & $<0.01$ \\
\hline
\end{tabular}

Table III: Effect of cinnamon on serum lipid profile of adult male rats fed with fatty mixture feed (C vs D)

\begin{tabular}{|l|c|c|c|}
\hline Parameters & $\begin{array}{c}\text { Group C }(\mathrm{n}=6) \\
\text { Mean } \pm \mathrm{SE}\end{array}$ & $\begin{array}{c}\text { Group D }(\mathrm{n}=6) \\
\text { Mean } \pm \mathrm{SE}\end{array}$ & P values \\
\hline $\begin{array}{l}\text { Serum total } \\
\text { cholesterol }(\mathrm{mg} / \mathrm{dL})\end{array}$ & $136 \pm 3.74$ & $119.5 \pm 2.68$ & $<0.01$ \\
$\begin{array}{l}\text { Serum TG }(\mathrm{mg} / \mathrm{dL}) \\
\begin{array}{l}\text { Serum HDL } \\
\text { cholesterol }(\mathrm{mg} / \mathrm{dL})\end{array}\end{array}$ & $30.81 \pm 2.78$ & $29.17 \pm 1.73$ & $>0.05$ \\
$\begin{array}{l}\text { Serum LDL } \\
\text { cholesterol }(\mathrm{mg} / \mathrm{dL})\end{array}$ & $83.81 \pm 5.61$ & $71.91 \pm 1.88$ & $<0.05$
\end{tabular}

Table IV: Comparison of effects of cinnamon and atorvastatin on serum lipid profile of fatty mixture diet fed adult male rats (D vs E)

\begin{tabular}{|l|c|c|c|}
\hline Parameters & $\begin{array}{c}\text { Group D }(\mathrm{n}=6) \\
\text { Mean } \pm \mathrm{SE}\end{array}$ & $\begin{array}{c}\text { Group E }(\mathrm{n}=6) \\
\text { Mean } \pm \mathrm{SE}\end{array}$ & P values \\
\hline $\begin{array}{l}\text { Serum total } \\
\text { cholesterol }(\mathrm{mg} / \mathrm{dL})\end{array}$ & $119.5 \pm 2.68$ & $83.83 \pm 3.51$ & $<0.01$ \\
$\begin{array}{l}\text { Serum TG }(\mathrm{mg} / \mathrm{dL}) \\
\begin{array}{l}\text { Serum HDL } \\
\text { cholesterol }(\mathrm{mg} / \mathrm{dL})\end{array}\end{array}$ & $29.13 \pm 3.02$ & $75.67 \pm 2.18$ & $<0.01$ \\
$\begin{array}{l}\text { Serum LDL } \\
\text { cholesterol }(\mathrm{mg} / \mathrm{dL})\end{array}$ & $71.91 \pm 1.88$ & $30.50 \pm 2.09$ & $>0.05$ \\
\hline & $38.20 \pm 3.73$ & $<0.01$ \\
\hline
\end{tabular}

\section{Discussion}

A growing body of research has demonstrated that the commonly used herbs and spices such as garlic, black cumin, cloves, cinnamon, thyme, five spices, bay leaves, mustard and rosemary possess antimicrobial properties and can be used therapeutically in some cases. ${ }^{7}$
Medicinal plants play a vital role for the development of new drugs. The bioactive extract should be standardized on the basis of active compound and should undergo safety studies. Almost $70 \%$ of modern medicines in India are derived from natural products. Medicinal plants play a central role not only as traditional medicines but also as trade commodities, meeting the demand of distant markets. $^{8}$

In experiment I, all conventionally measured indicators (serum cholesterol, TG, LDL, and HDL levels) of lipid profiles were slightly changed in Group B as compared to those in the control Group A. But changes were not statistically significant. These findings support the findings of another similar study. ${ }^{9}$

In experiment II, the effect of Cinnamomum cassia was observed on serum lipid profile of hyperlipidemic Long Evans rats. On administrating the fatty diet, Group $\mathrm{C}$ showed significant $(\mathrm{P}<0.01)$ increase of serum lipid profile parameters (TC, TG, LDL-C) compared to those of control group (Group A). This finding indicates that fatty mixture diet that is used to elevate the serum lipid profile parameters was able to elevate all parameters except HDL-C measured in this experiment. Similar study done by Javed et a ${ }^{10}$ supports the present study.

It was found in this study that $15 \%$ cinnamon powder significantly decreased the serum TC, TG, LDL-C approximately by $12 \%, 11 \%$ and $14 \%$ respectively $(\mathrm{P}<0.01, \mathrm{P}<0.01$ and $\mathrm{P}<0.05)$ of fatty mixture diet fed rats; but HDL-C level was not significantly changed. Soheir et al ${ }^{11}$ administered $15 \%$ cinnamon powder in hypercholesterolemic diabetic rats and found decreased plasma cholesterol from 268 to 121 $\mathrm{mg} / \mathrm{dL}$ (54\%), TG levels from $228 \mathrm{mg} / \mathrm{dL}$ to $100 \mathrm{mg} / \mathrm{dL}(56 \%)$ and LDL-C from $211 \mathrm{mg} / \mathrm{dL}$ to $61 \mathrm{mg} / \mathrm{dL}$ (71\%) and HDL-C increased from $36 \mathrm{mg} / \mathrm{dL}$ to $63 \mathrm{mg} / \mathrm{dL}(75 \%)$. As Soheir et al performed their study on diabetic rats fed on basal diet (corn starch $70 \%$, casein $10 \%$, corn seed oil $10 \%$, cellulose $5 \%$, salt mixture $4 \%$ and vitamins mixture $1 \%$ ), this might be the 
possible cause of difference in lipid-lowering effects of cinnamon between these studies.

In this study administration of atorvastatin at 0.2 $\mathrm{mg} / \mathrm{kg}$ body weight for 35 days decreased serum cholesterol, TG, LDL-C approximately by $38 \%, 28 \%$ and $54 \%$ respectively of fatty mixture diet fed rats. HDL-C level was not changed significantly. These findings support study of Amin et al. ${ }^{4}$

Cinnamon might have a direct role in lipid metabolism and prevent hypercholesterolemia and hypertriglyceridemia and lower free fatty acids by its strong lipolytic activity. Dietary cinnamate inhibits the hepatic HMG Co-A reductase activity resulting in lower hepatic cholesterol content and suppresses lipid peroxidation via enhancement of hepatic antioxidant enzyme activity. ${ }^{12}$

Cinnamomum cassia may have an effect on treating hyperlipidemia and thereby may be responsible for the prevention of consequences of the aging process, from hypertension to heart failure, cardiovascular diseases and myocardial infarction. Therefore, further studies could establish the effect of Cinnamomum cassia on hyperlipidemic human beings.

From the findings of the present study, it can be concluded that Cinnamomum cassia has hypolipidemic effect on hypercholesterolemic rats under different experimental conditions. Before establishing Cinnamomum cassia as a therapeutically effective hypolipidemic agent, further studies should be carried out to determine the active principle responsible for hypolipidemic effect and its cellular mechanism of action.

\section{References}

1. Adaramoye OA, Akintayo O, Achem J, Fafunso MA. Lipid-lowering effects of methanolic extract of vernonia amygdalina leaves in rats fed on high cholesterol diet. Vascular health \& Risk Management 2008; 4(1): 235-241.
2. Owen OJ, Amakiri AO, Karibi-Botoye TA. Lipid lowering effect of bitter leaf (Vernonia amygdalina) in broiler chickens fed finishers mash. Agric Biol J N Am 2011; 2(6): 1038-1041.

3. Moll J, Foster. Cinamon: Does it lower cholesterol levels? Available at: http://cholesterol.about.com/od/ naturalalternatives /a/cinnamon.htm. Accessed January 2013.

4. Amin KA, AbdEL-Twab TM. Oxidative markers, nitric oxide and homocysteine alteration in hypercholesterolemic rats: role of atorvastatin and cinnamon. Int J Clin Exp Med 2009; 2(3): 254-265.

5. Anderson RA, Broadhurst CL, Polansky MM, Schmidt WF, Khan A, Flanagan VP et al. Isolation and characterization of polyphenol type-A polymers from cinnamon with insulin like biological activity. J Agri Food Chem 2004; 52(1): 65-70.

6. Leung AY, Foster. Encyclopedia of common natural ingredients used in food, drugs and cosmetics. 2nd edn. New York: John Wiley \& Sons, 1996.

7. Lai PK, Roy J. Antimicrobial and chemopreventive properties of herbs and spices. Curr Med Chem 2004; 11(11): 1451-1460.

8. Verma S, Singh SP. Current and future status of herbal medicines. Veterinary World 2008; 1(11): 347-350.

9. Amin R. Anti-obesity effect of mushroom (Ganoderma Lucidum) on experimentally induced obese rats, AKMMC J 2012; 3(2): 11-14.

10. Javed I, Faisal I, Khan MZ, Rahman Z, Muhammad F, Aslam B et al. Lipid lowering effect of cinnamomum zeylanicum in hyperlipidemic albino rabbit. Pakistan $\mathrm{J}$ Pharm Sci 2012; 25(1): 141-147.

11. Soheir N, Abd El. Rahman, Amal M.H. Abdel-Haleem, Hessa M. AL Mudhaffar. Anti-diabetic effect of cinnamon powder and cinnamon aqueous extract on serum glucose of rats. International Journal of Food, Nutrition and Public Health 2010; 3(2): 183-197.

12. Lee JS, Jeon SM, Park EM, Huh TL, Kwon OS, Lee MK et al. Cinnamate supplementation enhances hepatic lipid metabolism and anti oxidant defense systems in high cholesterol fed rat. J. Medicinal Food 2003; 6(3): 183-191. 